\title{
Perubahan Viabilitas Pollen dan Anatomi Stomata pada Dua Mutan Tomat, iaa9-3 dan iaa9-5, akibat Cekaman Suhu Tinggi
}

\author{
Fitrianti Widya Lestari ${ }^{1}$, Erni Suminar ${ }^{2}$, Anne Nuraini $^{2}$, Hiroshi Ezura ${ }^{3}$, \\ dan Syariful Mubarok ${ }^{2 *}$ \\ ${ }^{1}$ Program Pascasarjana Agronomi Fakultas Pertanian Universitas Padjadjaran, Indonesia \\ ${ }^{2}$ Departemen Agronomi Fakultas Pertanian Universitas Padjadjaran, Indonesis \\ ${ }^{3}$ Faculty Life and Environmental Sciences, University of Tsukuba, Japan \\ *Alamat korespondensi: syariful.mubarok@unpad.ac.id
}

\begin{abstract}
Changes of pollen viability and stomatal anatomy in two tomato mutant of iaa9-3 and iaa9-5, as a result of heat stress
\end{abstract}

High temperature is one of the main abiotic stresses (heat stress) that limit the growth and development of tomato plants. Heat stress causes the failure of pollen development and low pollen viability. Heat stress also causes anatomic changes, including stomata on the leaves. In this study, iaa9-3 and iaa9-5 tomato mutants were tested, and $W T-M T$ as control with two different temperature conditions. iaa9-3 and iaa9-5 are the mutant of tomatao plant cv Micro-Tom with a genetic mutation in specific IAA9 genes, that act as a negative regulator of auxin responses. Plants were treated with a maximum temperature of $30-35{ }^{\circ} \mathrm{C}$ and $40-45^{\circ} \mathrm{C}$ for 3 hours every day. The results showed that the number of viable pollen and semi-viable pollen were increased in iaa9-3 and iaa9-5 mutants whereas the number of dead pollen was reduced, compared to $W T-M T$ when grown at $30-35{ }^{\circ} \mathrm{C}$ and $40-45{ }^{\circ} \mathrm{C}$. The number of viable pollen and semi-viable pollen in iaa9-3 mutants, iaa $9-5$ mutants and $W T-M T$ grown at $40-45^{\circ} \mathrm{C}$ was less than when they were grown at $30-35{ }^{\circ} \mathrm{C}$, while the number of dead pollen was increased. The number of leaf stomata (abaxial) at the iaa9-5 and iaa9-3 mutants increased compared to $W T-M T$ at temperatures of $30-35{ }^{\circ} \mathrm{C}$ and $40-$ $45^{\circ} \mathrm{C}$. The number of stomata on iaa9-3 and iaa9-5 mutant and $W T-M T$ at a temperature of 30-35 ${ }^{\circ} \mathrm{C}$ was more than the number of stomata on the iaa9-3 and iaa9-5 mutant and WT-MT at a temperature of $40-45^{\circ} \mathrm{C}$. This indicated that heat stress causes the number of stomata to decrease.

Keywords: Mutation, Pollen, Stomata

\begin{abstract}
ABSTRAK
Cekaman suhu tinggi merupakan salah satu cekaman abiotik utama yang membatasi pertumbuhan dan perkembangan tanaman tomat. Hal tersebut menyebabkan kegagalan perkembangan serbuk sari dan rendahnya viabilitas polen. Heat stress juga menyebabkan perubahan anatomi salah satunya stomata pada daun. Pada penelitian ini diuji dua tanaman tomat mutan iaa9-3 dan iaa9-5, serta $W T-M T$ sebagai kontrol dengan dua kondisi suhu yang berbeda. Mutan iaa9-3 dan iaa9-5 merupakan tanaman tomat kultivar Micro-Tom yang mengalami mutasi genetik pada gen spesifik IAA9 yang berperan sebagai regulator respons auksin negatif. Tanaman dipaparkan pada suhu maksimum $30-35^{\circ} \mathrm{C}$ dan $40-45^{\circ} \mathrm{C}$ selama 3 jam setiap harinya. Hasilnya menunjukkan bahwa pada mutan iaa9-3 dan iaa9-5 jumlah polen viabel dan polen semiviabel meningkat, serta jumlah polen mati menurun dibandingkan $W T-M T$ baik pada suhu $30-35^{\circ} \mathrm{C}$ maupun suhu $40-45^{\circ} \mathrm{C}$. Perbandingan jumlah polen viabel dan polen semiviabel pada mutan iaa9-3, mutan iaa9-5 dan $W T$ $M T$ pada suhu $40-45^{\circ} \mathrm{C}$ lebih sedikit dibandingkan pada suhu $30-35^{\circ} \mathrm{C}$, sedangkan jumlah polen mati lebih banyak. Mutan iaa9-5 dan iaa9-3 memiliki jumlah stomata daun (abaxial) yang lebih banyak dibandingkan dengan $W T-M T$ baik pada suhu $30-35^{\circ} \mathrm{C}$ maupun $40-45^{\circ} \mathrm{C}$. Jumlah stomata mutan iaa9-3 dan iaa9-5 serta $W T-M T$ pada suhu $30-35{ }^{\circ} \mathrm{C}$ lebih banyak dibandingkan jumlah
\end{abstract}


stomata mutan iaa9-3 dan iaa9-5 serta $W T-M T$ pada suhu $40-45{ }^{\circ} \mathrm{C}$. Cekaman suhu tinggi menyebabkan penurunan jumlah stomata.

Kata kunci: mutasi, polen, stomata

\section{PENDAHULUAN}

Tomat (Solanum lycopersicum) merupakan komoditas hortikultura dari famili Solanaceae yang sangat penting dan banyak diminati masyarakat. Tomat umumnya dimanfaatkan sebagai bahan pangan sumber nutrisi dan antioksidan. Menurut Pusat Data dan Informasi Pertanian (2017) proyeksi konsumsi tomat tahun 2017 hingga 2021 diperkirakan naik dengan rata-rata pertumbuhan $5,32 \%$ per tahunnya, sedangkan produksi tomat di Indonesia pada tahun 2018 hanya mengalami peningkatan sebesar 1,45\% dari tahun 2017 (BPS, 2019). Rendahnya peningkatan produksi dapat disebabkan oleh keterbatasan budidaya tomat yaitu faktor eksternal (lingkungan tumbuh) dan faktor internal (aktivitas hormon dan genetika) yang mempengaruhi pertumbuhan dan perkembangan tomat (Shibasaki \& Rahman, 2013).

Suhu merupakan faktor eksternal yang membatasi budidaya tanaman tomat. Menurut Intergovernmental Panel on Climatic Change (2014) rata-rata suhu dunia meningkat $0,3^{\circ} \mathrm{C}$ di setiap negara akibat adanya global warming dan diprediksikan akan meningkat $3^{\circ} \mathrm{C}$ dari temperatur biasanya pada tahun 2100. Menurut Ariizumi et al. (2013) suhu lingkungan yang melebihi $4^{\circ} \mathrm{C}$ dari suhu optimal, akan menyebabkan aborsi perkembangan polen. Peningkatan suhu mempengaruhi percepatan pembungaan, terbentuknya bunga jantan yang mandul, menghambat perkembangan gamet dan embrio, serta menghambat kemampuan bunga yang diserbuki untuk berkembang menjadi buah (Solankey et al., 2015). Kegagalan perkembangan polen dan rendahnya viabilitas polen merupakan penyebab utama kegagalan pembentukan buah pada tanaman tomat saat berada pada suhu tinggi (Hoshikawa, 2017). Perubahan anatomis tanaman seperti perkembangan stomata juga dipengaruhi oleh suhu tinggi. Ontogenesis stomata merupakan elemen kunci adaptasi tanaman yang bertujuan untuk mengendalikan efisiensi fotosintesis dan pengelolaan air dalam lingkungan yang berfluktuasi (Samakovli et al., 2018).

Tanaman tomat mutan iaa9-3 dan iaa9-5 berasal dari tanaman Wild-Type Micro-Tom (WTMT) yang dibentuk melalui mutasi dengan mutagenesis ethyl methyl sulfonate (EMS) (Just et al., 2013). Mutan iaa9-3 dan iaa9-5 mengalami mutasi genetik pada gen spesifik IAA9 (Saito et al, 2011). $I A A 9$ merupakan family dari gen $A u x / I A A$ yang memiliki peran sebagai penekan transkripsi jalur sinyal auksin endogen yaitu Indole Acetic Acid (IAA) (Guilfoyle \& Hagen, 2007). Proteolisis pada family gen $A u x / I A A$, akan menyebabkan ARF (Auxin Respons Factors) dan IAA9 saling berikatan sehingga terjadi peningkatan respons auksin endogen (Saito et al., 2011). Maka saat terjadi gangguan yang diperoleh dari mutasi pada IAAO akan memicu respons auksin diberbagai tempat (Wang et al., 2005).

Auksin berperan dalam adaptasi tanaman terhadap cekaman suhu tinggi. Keberadaan auksin dapat menghasilkan produksi polen yang normal, dan meningkatkan viabilitas polen pada kondisi heat stress (Higashitani, 2013). Secara anatomis auksin yang terkandung dalam tanaman dapat mempengaruhi jumlah dan pola stomata (Le et al., 2014). Penelitian ini bertujuan untuk mengetahui respon mutan tomat iaa9-3 dan iaa9-5 terhadap viabilitas polen dan anatomis stomata akibat cekaman suhu tinggi (heat stress).

\section{BAHAN DAN METODE}

Penanaman dilaksanakan di Lahan
Percobaan Ciwidey, Kabupaten Bandung. Pengamatan jumlah stomata dan viabilitas polen dilaksanakan di Laboratorium Analisis Tanaman dan Pasca Panen Hortikultura Fakultas Pertanian Universitas Padjadjaran. Tanaman dipindahkankan secara keseluruhan beserta pot dari lapangan menuju laboratorium. Rancangan penelitian yang digunakan yaitu single plant yang terdiri dari 6 perlakuan dengan 4 ulangan. Rancangan analisis data hasil pengamatan menggunakan analisis Student's T-Test. Pada penelitian ini digunakan dua mutan tomat iaa 9 yaitu mutan iaa9-3 dan iaa9-5 serta WT-MT sebagai kontrol yang diberi perlakuan kondisi suhu normal dan cekaman suhu tinggi. Mutan iaa9-3 dan iaa9-5 berasal dari tanaman Wild-Type Micro-Tom (WTMT) dibentuk melalui mutasi dengan mutagenesis ethyl methyl sulfonate (EMS) (Just et al., 2013). Perlakuan suhu yang digunakan yaitu suhu normal 
dengan kisaran suhu maksimum $30-35^{\circ} \mathrm{C}$ selama 3 jam yaitu pada pukul 11.00 hingga $14.00 \mathrm{WIB}$, dan suhu heat stress dengan kisaran suhu maksimum 40$45{ }^{\circ} \mathrm{C}$ selama 3 jam yaitu pada pukul 11.00 hingga 14.00 WIB. Penanaman dilakukan pada musim kemarau, sehingga suhu tersebut merupakan ratarata kisaran suhu pada waktu tersebut.

Setting perlakuan untuk uji suhu pada lahan percobaan menggunakan dua meja modifikasi dengan ukuran 1 x 1,5 m yang dibuat untuk tempat penyimpanan tanaman. Modifikasi meja plastic perlakuan suhu normal atau $30-35{ }^{\circ} \mathrm{C}$ yaitu memiliki atap plastik Polyethylene dan dinding tanpa plastik. Pada perlakuan suhu heat stress atau $40-45^{\circ} \mathrm{C}$ meja perlakuan memiliki dinding dan atap plastic Polyethylene serta pada permukaannya dilapisi seng alumunium. Perlakuan suhu dimulai pada saat pindah tanam hingga akhir masa panen. Benih iaa93 dan iaa9-5, serta $W T-M T$ disemai selama 14 hari. Pindah tanam dilakukan pada pot plastik dengan diameter $15 \mathrm{~cm}$, dengan media arang sekam dan cocopeat 1:1.

Analisis anatomis stomata dilakukan dengan menggunakan metode Whole Mount (Saas, 1951) yaitu mengambil bagian epidermis bawah daun ke empat, pewarnaan safranin $1 \%$ lalu ditempatkan pada one cell counter untuk mempermudah perhitungan luas bidang untuk perhitungan stomata, kemudian diamati dengan mikroskop cahaya Optima H-903. Analisis viabilitas polen dilakukan dengan mengumpulkan polen dari bunga $1 \mathrm{DAF}$ (day after antesis) sebanyak 3 bunga per ulangan. Anter pada bunga diambil kemudian direndam pada larutan TTC (1\% TTC) dan sukrosa 50\% dan dibiarkan di ruangan gelap pada $38{ }^{\circ} \mathrm{C}$ selama 3 jam untuk mewarnai polen. Supernatan sebanyak $2 \mu$ diambil dan dimasukkan ke dalam cell counter. Polen kemudian diamati di bawah mikroskop. Kriteria polen viable yaitu polen yang menyerap warna merah dari larutan TTC. Perhitungan polen di lakukan per $1 \mathrm{~mm}^{2}$ cell counter.

\section{HASIL DAN PEMBAHASAN}

\section{Viabilitas Polen}

Viabilitas polen diamati secara mikroskopik. Hasil pengamatan terhadap viabilitas polen secara mikroskopik terdapat tiga kategori warna pada polen diantaranya (1) merah hingga merah kehitaman menunjukkan polen viabel, (2) warna merah pudar atau orange menunjukkan polen semi viabel, dan (3) polen tidak berwarna atau transparan menunjukkan polen mati (Gambar 1).

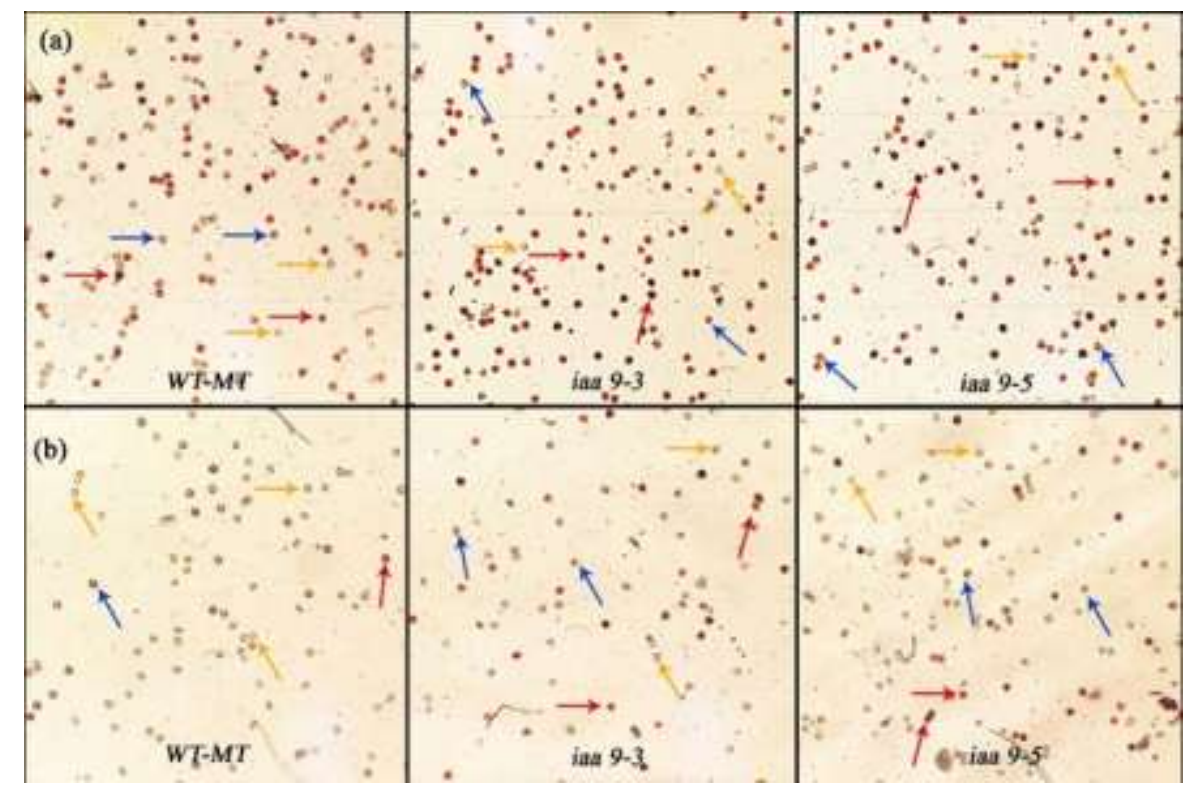

Gambar 1. Hasil mikroskopik analisis viabilitas polen per $1 \mathrm{~mm}$ preparat (a) suhu $30-35^{\circ} \mathrm{C}$ (b) suhu $40-45^{\circ} \mathrm{C}$. Ket. panah merah menunjukkan polen viabel, panah biru menunjukkan polen semiviabel, panah kuning menunjukkan polen mati.

Hasil pengamatan menunjukkan jumlah polen viable pada mutan iaa9-3 dan iaa9-5 lebih tinggi (Gambar 2a), sementara jumlah polen semiviabel lebih rendah (Gambar 2b) dan demikian pula dengan jumlah polen mati (Gambar 2c). Hal tersebut ditemukan pada dua kondisi percobaan baik pada suhu $30-35^{\circ} \mathrm{C}$ maupun suhu $40-45^{\circ} \mathrm{C}$. Menurut Aloni et al. (2006) auksin endogen atau IAA 
berperan dalam pertumbuhan tabung polen yang akan menuju ovula, dibuktikan dengan peningkatan konsentrasi IAA pada putik setelah terjadi penyerbukan. Pengaplikasian auksin dapat meningkatkan panjang anter, mencegah aborsi serbuk sari dan memperbaiki viabilitas serbuk sari dewasa (Sakata et al., 2010). Auksin dapat memblok perubahan traskripsional, yang menghasilkan produksi polen yang normal dan mencegah sterilitas polen pada kondisi cekaman suhu (Higashitani,
2013). Menurut Pan et al. (2018) IAA dapat meningkatkan berat segar stamen dan pistils pada bunga tomat saat terpapar cekaman suhu. Pada suhu 40-45 ${ }^{\circ} \mathrm{C}, W T-M T$ memiliki jumlah polen viabel dan semiviabel paling rendah dan jumlah polen mati tertinggi dibandingkan mutan iaa9-3 dan iaa9-5. Hal tersebut menunjukkan bahwa $W T-M T$ memiliki potensi kemandulan bunga jantan tertinggi.

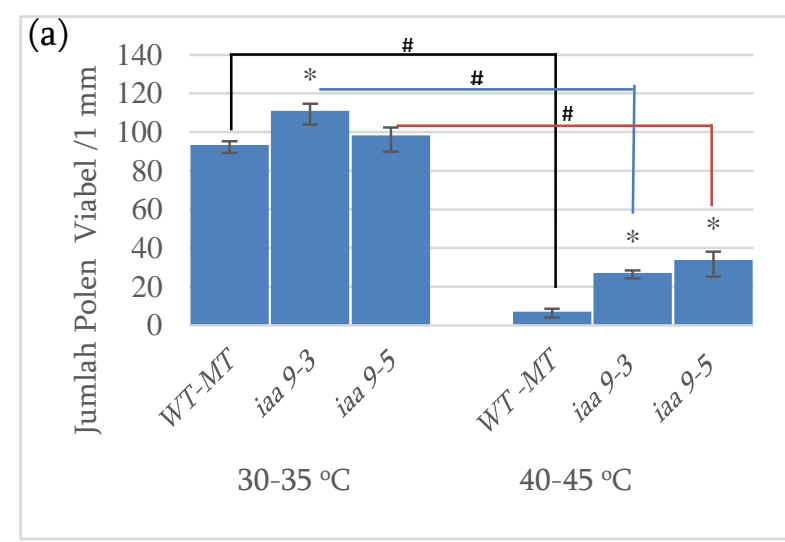

(b)

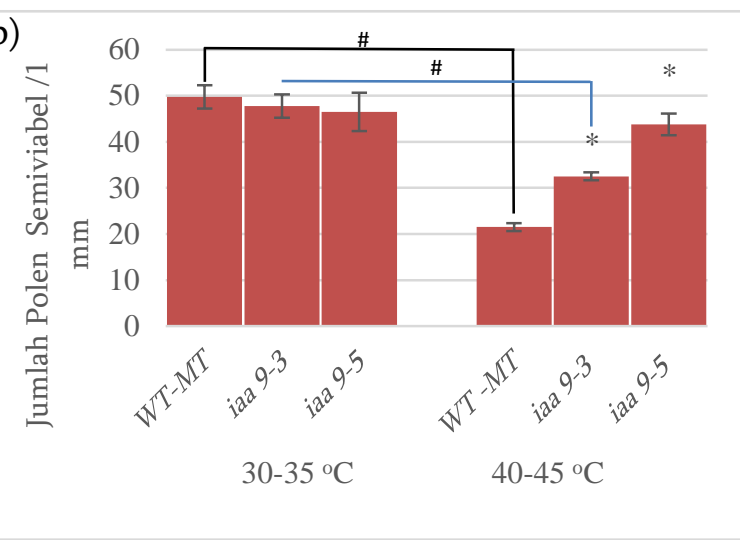

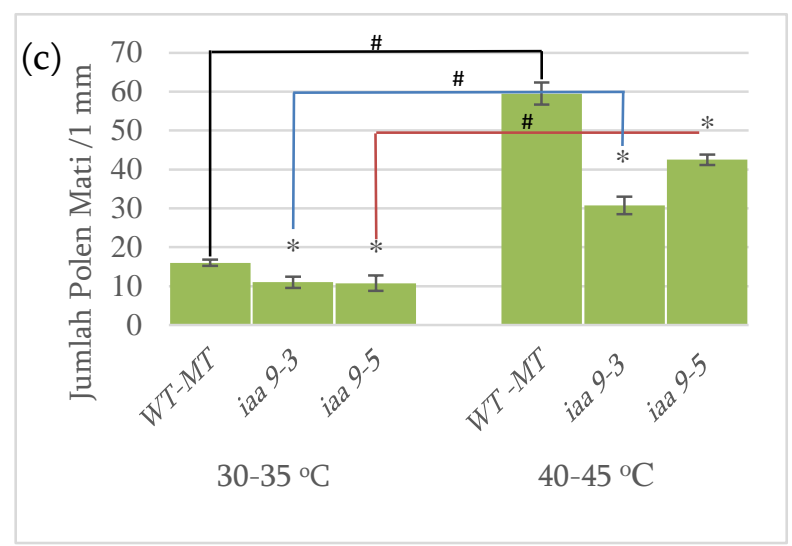

Gambar 2. Jumlah polen (a) viabel, (b) semiviabel, dan (c) polen mati dua tomat mutan pada suhu $30-35^{\circ} \mathrm{C}$ dan $40-45^{\circ} \mathrm{C}$.

- Nilai rata-rata \pm Standar Error (SE) (n =4) yang diikuti dengan lambang bintang $\left(^{*}\right)$ menunjukkan berbeda nyata dibandingkan kontrol (WT-MT) pada suhu $30-35{ }^{\circ} \mathrm{C}$ dan $40-45$ ${ }^{\circ} \mathrm{C}$ menurut uji Student's T-Test pada taraf $\mathrm{p}<0,05$.

- Nilai rata-rata \pm Standar Error (SE) (n =4) yang diikuti dengan lambang pagar (\#) menunjukkan adanya perbedaan yang signifikan setiap mutan antar dua kondisi suhu menurut uji Student's T-Test pada taraf $\mathrm{p}<0,05$.

Viabilitas polen pada mutan iaa9-3, mutan iaa9-5 dan $W T-M T$ menurun seiring dengan peningkatan suhu, sedangkan polen mati meningkat seiring dengan peningkatan suhu. Cekaman suhu tinggi berdampak terhadap peningkatan resiko kemandulan bunga jantan, aborsi serbuk sari hingga gagalnya pembuahan (Higashitani, 2013). Menurut Wang et al. (2017) cekaman suhu tinggi menyebabkan viabilitas polen menurun lebih dari $50 \%$, dan berpengaruh terhadap penurunan female atau ovule fertility serta penerimaan stigma. Menurut Faruq et al. (2012) cekaman suhu tinggi berdampak negatif terhadap proses meiosis (premature), perkecambahan polen, perkembangan ovula dan peningkatan viabilitas embrio. Pada tanaman tomat, suhu lingkungan yang tinggi dapat 
mempengaruhi meiosis pada organ jantan dan betina, degradasi dinding sel anter, polen germinasi dan perkembangan tabung polen, viabilitas ovula, jumlah polen pada stigma dan fertilisasi (Zargar \& Zargar, 2018).

\section{Jumlah Stomata}

Jumlah stomata pada daun (abaxial) tanaman tomat mutan iaa9-5 dan iaa9-3 lebih tunggi dibandingkan dengan $W T-M T$ baik pada suhu suhu 30-35 ${ }^{\circ} \mathrm{C}$ maupun $40-45{ }^{\circ} \mathrm{C}$ (Gambar 3). Hal ini disinyalir karena terjadinya mutasi pada gen IAA9 yang dialami kedua tomat mutan tersebut.
Balcerowicz \& Hoecker (2014) menyatakan bahwa pembentukan dan distribusi stomata dipengaruhi oleh jalur persinyalan auksin. Pembentukan stomata terdiri dari unequal division yaitu pembelahan sel meristemoid (Ms) secara asimetris kemudian equal division yaitu pembelahan guard mother cells (GMCs) secara simetris yang berkembang menjadi dua sel penjaga stomata, peningkatan level auksin terlihat selama fase transisi Ms ke GMC (Le et al., 2014). Auksin dapat mengontrol pembelahan dan diferensiasi sel-sel jalur pembentukan stomata (Balcerowicz \& Hoecker, 2014).

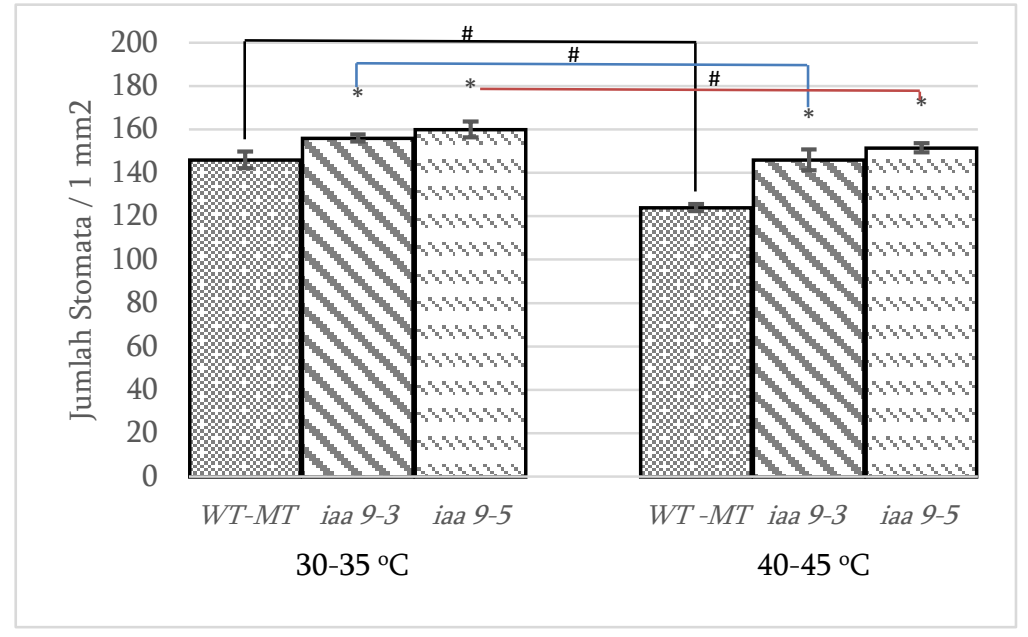

Gambar 3. Jumlah stomata pada suhu $30-35^{\circ} \mathrm{C}$ dan $40-45^{\circ} \mathrm{C}$.

- Nilai rata-rata \pm Standar Error (SE) (n = 4) yang diikuti dengan lambang bintang $\left(^{*}\right)$ menunjukkan berbeda nyata dibandingkan kontrol ( $W T-M T$ ) pada suhu $30-35{ }^{\circ} \mathrm{C}$ dan $40-45$ ${ }^{\circ} \mathrm{C}$ menurut uji Student's T-Test pada taraf $\mathrm{p}<0,05$.

- Nilai rata-rata \pm Standar Error (SE) (n = 4) yang diikuti dengan lambang pagar (\#) menunjukkan adanya perbedaan yang signifikan setiap mutan antar dua kondisi suhu menurut uji Student's T-Test pada taraf $\mathrm{p}<0,05$.

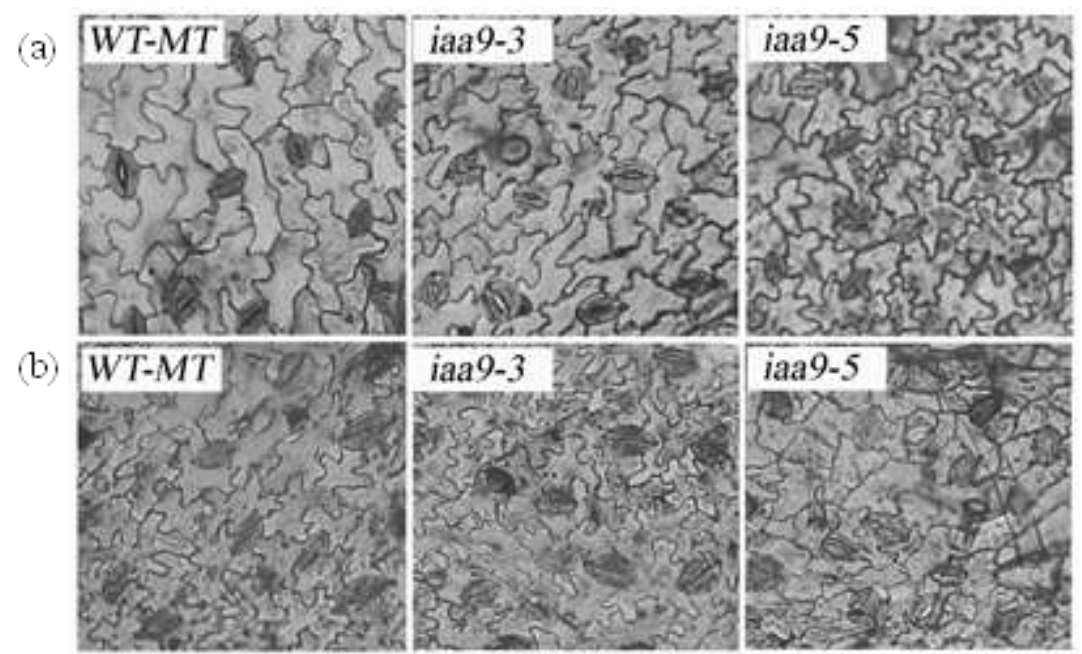

Gambar 4. Kondisi stomata per $0.5 \mathrm{~mm}^{2}$ pada daun tanaman tomat yang ditumbuhkan pada (a) suhu 30$35^{\circ} \mathrm{C}$, dan (b) suhu $40-45^{\circ} \mathrm{C}$. 
Jumlah stomata mutan iaa9-3 dan iaa9-5 serta $W T-M T$ pada suhu $30-35^{\circ} \mathrm{C}$ ditemukan lebih banyak dibandingkan jumlah stomata pada tomat mutan iaa9-3 dan iaa9-5 serta WT-MT yang ditumbuhkan pada kondisi suhu $40-45^{\circ} \mathrm{C}$. Kehilangan air terus menerus akan menimbulkan efek dehidrasi pada tanaman, sehingga tanaman akan mengurangi kepadatan, dimensi serta luas stomata pada daun untuk mempertahankan potensi air jaringan (Kusvuran et al., 2010). Regulasi stomata terhadap transpirasi merupakan strategi dari tanaman untuk mengurangi kehilangan air dengan menutup atau mengurangi jumlah stomata sebagai respon terhadap cekaman abiotik (Anosheh et al., 2018). Hal ini sesuai dengan hasil penelitian yang diperoleh yang menunjukkan pada kondisi tercekam (suhu tinggi) stomata akan menutup (Gambar 4). Adaptasi tanaman terhadap suhu tinggi suhu 40$45^{\circ} \mathrm{C}$ salah satunya mengurangi jumlah stomata dan kepadatan stomata.

\section{SIMPULAN}

Pada tomat mutan iaa9-3 dan iaa9-5 viabilitas polen dan jumlah stomata lebih tinggi dibandingkan $W T-M T$ pada suhu $30-35^{\circ} \mathrm{C}$ maupun $40-45^{\circ} \mathrm{C}$. Sementara viabilitas polen dan jumlah stomata pada mutan iaa9-3, iaa9-5 dan $W T-M T$ yang ditanam pada suhu $40-45^{\circ} \mathrm{C}$ lebih rendah dibandingkan mutan iaa9-3, iaa9-5 dan WT-MT yang ditanam pada suhu $30-35{ }^{\circ} \mathrm{C}$. Cekaman suhu tinggi disinyalir dapat menurunkan viabilitas polen dan jumlah stomata pada mutan iaa9-3, iaa9-5 dan WT-MT.

\section{UCAPAN TERIMA KASIH}

Ucapan terima kasih kami sampaikan ke semua pihak yang telah membantu penyelesaian penelitian, dan kepada Ditjen Dikti untuk mendukung pekerjaan ini melalui hibah pada skema Hibah Thesis. Kami juga berterima kasih kepada Gene Research Center, University of Tsukuba Jepang, yang telah menyediakan benih $S$. lycopersicum cv. Micro-Tom, iaa9-3 dan iaa9-5. Kami juga berterima kasih kepada semua anggota laboratorium kami untuk diskusi bermanfaat selama bekerja.

\section{DAFTAR PUSTAKA}

Aloni, R, E Aloni, AEM Langhans, and CI Ullrich.
2006. Role of auxin in regulating Arabidopsis flower development. Planta. 223: 315-328.

Anosheh, HP, AS Moucheshi, H Pakniyat, and M Pessarakli. 2018. Stomatal responses to drought stress. Pp. 24-40 in Water Stress and Crop Plants: A Sustainable Approach, Volume 1, First Edition. (John Willey \& Sons).Wiley Blackwell.

Ariizumi, T, Y Shinozaki, and H Ezura. 2013. Genes that influence yield in tomato. Breeding Science. 63: 3-13.

Badan Pusat Statistik. 2019. Statistik Tanaman Sayuran dan Buah-buahan Semusim Indonesia. Badan Pusat Statistik Direktorat Jendral Hortikultura.

Balcerowicz, M, and U Hoecker. 2014. Auxin - a novel regulator of stomata differentiation. Trends in Plant Science. 19: 747-749.

Faruq, G, A Nezhadahmadi, and Z Prodhan. 2012. Heat tolerance in tomato. Life Science Journal. 9: 1936-1950.

Guilfoyle, J, and G Hagen. 2007. Auxin response factors. Plant Cell and Environment. 39: 10141028.

Higashitani, A. 2013. High temperature injury and auxin biosynthesis in microsporogenesis. Frontiers in Plant Science. 4: 2007-2010.

Hoshikawa, K, H Ezura, S Fukumoto, S Ooshima, and M Aiba. 2017. Heat-tolerant tomato mutant and method for producing the same. Patent Application Publication. 1: 1-59.

IPCC. 2014. Climate Change 2014: Impacts, Adaptation, and Vulnerability. IPCC WGII AR5. 1: 1-44.

Just, D, V Garcia, L Fernandez, C Bres, JP Mauxion, J Petit, and C Rothan. 2013. Micro-Tom mutants for functional analysis of target genes and discovery of new alleles in tomato. Plant Biotechnology. 30: 225-231.

Kusvuran, S, HY Dasgan, and C Paper. 2010. Relationship between drought tolerance and stomata density in melon relationship between drought tolerance and stomata density in melon. Acta Hort. 871: 290-301.

Le, J, X Liu, and X Chen. 2014. Auxin transport and activity regulate stomatal patterning and development. Nature Communication. 1: 1-9.

Pan, C, C Jiao, A Lamin-samu, and Z Fei. 2018. Tomato stigma exsertion induced by high temperature is associated with the jasmonate signaling pathway. Plant Cell and Environment. 1: 1-56. 
Pusat Data dan Sistem Informasi Pertanian. 2017. Outlook Tanaman Pangan dan Hortikultura. Retrieved from https://aplikasi2.pertanian.go.id/bdsp/id/komod itas

Saas, J. 1951. Bothanical Microtechnique. Iowa, The Iowa State Collage Press.

Sakata, T, T Oshino, S Miura, M Tomabechi, Y Tsunaga, N Higashitani, and A Higashitani, A. 2010. Auxins reverse plant male sterility caused by high temperatures. PNAS. 107 :8569-8574.

Samakovli, D, T Tichá, M Ovečka, I Luptovčiak, V Zapletalová, Y Krasylenko, And J Šamaj. 2018. Environment and HSP90 modulate MAPK stomatal developmental pathway. Biorxiv. 1: $1-15$.

Shibasaki, K, and A Rahman. 2013. Auxin and temperature stress: Molecular and cellular perspectives. Springer. 17: 295-310.
Solankey, SS, RK Singh, DK Baranwal, DK Singh, SS Solankey, RK Singh, and DK Singh. 2015. Genetic expression of tomato for heat and drought stress tolerance: An overview. International Journal of Vegetable Science. 21: 496-515.

Wang, H, B Jones, Z Li, P Frasse, C Delalande, F Regad, S Chaabouni, and A Latche. 2005. The Ttmato $A u x / I A A$ transcription factor $I A A 9$ is involved in fruit development and leaf morphogenesis. The Plant Cell. 17: 2676-2692.

Wang, X, C Xu, X Cai, Q Wang, and S Dai. 2017. Heat-responsive photosynthetic and signaling pathways in plants: Insight from proteomics. International Journal of Molecular Sciences. 18: 1-19.

Zargar, SM, and MY Zargar. 2018. Plants: An Omics and Signaling in Mediated Sensing Perspective. Springer Sciences. 229 pp. 